\title{
DUALITÁSOK AZ EURÓPAI UNIÓ NAGYVÁROSHÁLÓZATÁNAK FEJLETTSÉGÉBEN AZ EZREDFORDULÓN
}

\author{
(Dualities in State of Development of City Network \\ in European Union at the Turn of Millennium)
}

\author{
JENEY LÁSZLÓ
}

\begin{abstract}
Kulcsszavak:
nagyváros NUTS3 fekvés városnagyság fejlettségikülönbségek Európai Unió

Az Európai Unió regionális tagoltságában kimutatott térbeli és társadalmi szabályszerüségek a nagyvároshálózaton belül is hagyományosan szerepet játszanak. A tágabban értelmezett ezredforduló időszakában a rendszerváltozás, az integrálódás és a globalizáció nem hagyta érintetlenül a nagyvároshálózatot sem. A nagyvárosok fejlettségi különbségein belül egy igen látványos kiegyenlitódési folyamat zajlik, amelyben nem csupán a volt szocialista országok, hanem a nyugati perifériák centrumainak gyors felzárkózása is szerepet játszik. Mindezek némiképp átrajzolják a korábban jellemzö modelleket. Az 1990-es évek közepén még meghatározó centrum-periféria kettösség halványodásával, az átlag feletti és az alatti térségek választóvonalának nyugatabbra tolódásával egy határozottabb nyugat-keleti lejtó látszik kibontakozni, miközben a legmarkánsabb fejlettségi lépcsó továbbra is az egykori vasfinggöny vonala marad. Bár a városméret továbbra sem meghatározó a gazdasági fejlettségben, enyhe mértékben erősödik a milliós metropoliszok elönye. Jelen tanulmány ezek számszerü igazolására tesz kisérletet többféle területi elemzési módszer felhasználásával.
\end{abstract}

\section{Bevezetés}

A 20. század végén az európai nagyvárosok fejlődésére ható tényezók alapvetően átalakultak. A globalizációval, a kelet-közép-európai országokban lezajló rendszerváltozással, illetve az egyre mélyebb és területileg egyre bỏvebb integrációs folyamattal az európai nagyvárosok eltéró fejlódési impulzusokat kapnak, ami differenciáló hatást gyakorol a Közösség városhálózatán belüli fejlettségi különbségek alakulására. Megélénkült a nagyvárosok közötti verseny, amelyben egyre több nagyváros vesz részt, az informatika korában akár egymástól nagyobb földrajzi távolságra fekvó városok is kölcsönhatásba kerülhetnek egymással, közülük a ,sikeres várost a tudás-alapú termelés jellemzi" (Enyedi 1997, 3). Így a jövő Európai Uniójának egyik legfontosabb kihívása éppen a tudástársadalmat magukhoz vonzó, majd onnan továbbsugározni képes nagyvárosok helyzetének alakítása.

A nyugati piacgazdaságokban már korábban megkezdỏdó, a globalizáció által felélénkített gazdasági átrendezódés után az európai városversenyt az 1990-es években a volt szocialista térség városainak bekapcsolódása tovább színesítette. A korábban még izoláló államhatárok megnyílása, a globális hatások gyors elterjedése, a transz- 
nacionális cégek megtelepedése, valamint az integrációs folyamat következtében az egykori Keleti Blokk nagyvárosai a világgazdaság részeivé váltak. A rendszerváltás előtt elszigetelt Kelet-Közép-Európa szoros kölcsönhatásba került az addig a vasfüggöny által elkülönített nyugat-európai városfejlödéssel, amely alapvető változásokhoz vezetett az összeurópai városhálózat fejlödésében is, hiszen a kelet-középeurópai nagyvárosoknak is esélyük teremtődött az európai urbanizációs tengelyekhez való csatlakozásra.

Az integráció hatására egységesülő európai gazdasági térben a szegényebb térségek (és azok nagyvárosai) számára megnyílik a lehetőség a gazdasági felzárkózásra, ezt részben a spontán piaci folyamatok (például az olcsó munkaerő vonzása miatt a multik telephelyválasztása), kisebb részben pedig egy tudatos, a kiegyenlítést célzó közösségi regionális politika segítik elö. Ráadásul a policentrikusan fejlődő Közösségen belül a kisebb gazdasági erővel rendelkező nagyvárosok számára is lehetőség nyílik új nemzetközi funkciók betöltésére a városversenyben (például Budapest esetében a határok „eltünéséből” adódóan erősödő jelenlét a Kárpát-medencében, kapuváros szerep a Balkán felé, éleződő versengés a kelet-közép-európai vezetö helyért Prágával és Varsóval szemben) (Enyedi 1996; 1998; 1999; Cséfalvay 1999; Lengyel 1999; Kovács 2002). A Közösség „Az Európai Unió területi helyzete és távlatai" (TSP) címủ dokumentumában megfogalmazza: „Az európai magtérségeken kívül számos olyan nagyvárosi térséget találunk, amelyeket meg kell erősíteni annak érdekében, hogy jobban kiaknázhassák a térségi potenciálokat és csökkenthessék a meglévő egyenlőtlenségeket, amely végső soron az európai térség harmonikusabb és policentrikusabb fejlődését segíti elo"." (idézi Faragó 2006, 93)

Persze az integrálódás, kiegészülve a globalizáció folyamatával nemcsak lehetőségként jelenik meg, hanem kihívást is támaszt. Számos tanulmány rávilágít arra, hogy a felerösödött versenyben kedvezöbb helyzetben vannak a hagyományosan is gazdagabb, agglomerációs előnyökkel, fejlett infrastruktúrával, a közlekedési és az információs hálózatokban kitủnő pozícióval, képzettebb társadalommal rendelkező legnagyobb metropoliszok (London vagy Párizs). Bernek Ágnes a transznacionális vállalatok központjainak helyválasztásával kapcsolatban kiemeli a globális városok előnyét: „A vállalati és regionális központok területi agglomerálódási folyamatokat eredményeznek. Adott területi agglomeráció megléte, illetve az ezt elősegítő tényezők önmagukban véve is meghatározó telepítési tényezőket jelentenek." (Bernek $2000,98)$ Mindez a nagyvároshálózaton belüli polarizációs tendenciák elmélyüléséhez vezethet a legnagyobb városok javára. „Ez a fejlödés egyelöre törést okoz a városhierarchia szerkezetében. Nemcsak arról van szó, hogy csak néhány város képes a globalizálódás által megújulni, gyors fejlődésnek indulni, hanem arról is, hogy a városhierarchiában ezeket a városokat követő szintek mélyen leszakadnak, visszaesnek. Egyelöre tehát a növekedés diffúziója a városhierarchián belül nem múködik." (Barta-Beluszky 1999, 22)

Láthatjuk, hogy egyszerre jelennek meg konvergáló és divergáló folyamatok a nagyvároshálózaton belül, kérdés azonban, hogy ezek az egymással szemben ható folyamatok együttesen hogyan formálják át az 21. század küszöbén az Európai 
Unióban megnỳilvánuló nyugat-keleti, észak-déli fejlettségi lejtőt, vagy a korábban - sokszor épp a nagyvárosokra alapozva - felállított, a centrumtérségek gazdasági előnyét hangsúlyozó térszerkezeti modelleket (például Brunet által az 1980-as évek végén bevezetett Kék Banánt). Mennyire számít a város nagysága a fejlődésben, eltünőben vannak-e az évtizedekig tartó politikai megosztottság nyomát viselö hagyományos törésvonalak a régi és az új tagállamok nagyvárosai között?

Részben a városokra vonatkozó harmonizált összeurópai statisztikák eddigi hiányával magyarázható, hogy az európai városhálózat, városhierarchia és városverseny különböző aspektusait elemző vizsgálatok között kevés terjed ki a kelet-középeurópai térség elemzésére is. Amelyek pedig igen (Enyedi 1996; 1997), azok e térséggel kapcsolatban többnyire általánosabb megállapításokat fogalmaztak meg, melyek közül az egyik legalapvetőbb az volt, hogy a rendszerváltás hatására az egykori szocialista országok nagyvárosai, de legalábbis a fövárosai is bekapcsolódtak az európai városok versenyébe, igaz a liberalizáció elsősorban a kereskedelemre és kevésbé a személyek migrációjára terjedt ki.

Jelen elemzés az Európai Unió nagyvárosai közötti gazdasági fejlettségi különbségek statisztikai vizsgálatára, illetve az azok hátterében rejlő összefüggések, szabályszerüségek kimutatására irányul. Néhány alapvető földrajzi és társadalmi változó segítségével megpróbálunk választ adni arra, hogy a földrajzi fekvés, a történelmi múlt vagy a méretgazdaságosság, mint független tényezők hogyan magyarázzák a nagyvárosok fejlettségi, fejlődési eltéréseit. Mutat-e a nagyvárosok fejlettségi térszerkezete bizonyos szabályszerüségeket egyes térparaméterek (pl. nyugatkeleti, észak-déli vagy központ-periféria) viszonylatban? Az 1990-es évek végétől a gazdaságilag nekilendülő Kelet-Közép-Európán belül a nagyvárosok különösen gyors fejlődési impulzust kaptak, de vajon képesek-e az integrációs folyamattal párhuzamosan felzárkózni az egykori Nyugati Blokkhoz? Végül arra is igyekszünk választ adni, hogy függ-e a mérettől a dinamika, azaz mely városméret-kategóriák esetében mutatható ki gyorsabb fejlődés?

\section{Vizsgálatba bevont nagyvárosok körének lehatárolása}

A köznyelvben és a szakirodalomban is viszonylag gyakran találkozunk a nagyváros fogalmával, azonban e szó pontos meghatározására nincs általánosan elfogadott definíció. Ez nem véletlen, hiszen már magának a város fogalmának is sokféle változata létezik az Európai Unió országaiban ${ }^{1}$ attól függően, hogy az adott országok milyen kritériumok alapján ítélik oda egy településnek a városi címet.

Nyilvánvaló, hogy a nagyvárosokat a nagyságuk különbözteti meg a többi várostól. Ez a nagyság azonban nem annyira a település területi kiterjedésére, sokkal inkább a lakóinak számára utal, illetve átvitt értelemben még a település városhierarchiában betöltött helyzetére is. A különböző tudományos publikációk (cikkek, statisztikák, atlaszok, enciklopédiák) általában egy konkrét népességszám-küszöbhöz kötik a nagyváros fogalmát. Jelen vizsgálatban is a nagyvárosok körének lehatárolását a népesség- 
szám alapján végeztük el, amely nem feltétlenül azonos a településhálózatban betöltött funkciókkal. Így előfordulhat, hogy az európai városhierarchia egyes magasabb szintjén lévô település nem került be az elemzésbe (például kisebb népességủ fỏvárosok, mint Pozsony, Ljubljana vagy Tallin), ugyanakkor egy-két, alacsonyabb funkciókkal rendelkező, legfeljebb regionális jelentőségủ központ (például Göteborg, Lipcse vagy Málaga) szerepel a vizsgált nagyvárosok között.

Ezek után további kérdésként merül fel, hogy mekkora népességszámot érdemes a nagyvárosok kijelölésénél figyelembe venni. A 20. század folyamán világszerte lezajlott, és máig tartó, kiugróan gyors ütemủ urbanizáció hatására a nagyváros fogalmához kötődó népességszám napjainkra jelentôsen megnőtt. „A századfordulón a 100000 lakosú városokat már nagyvárosoknak tekintették, ma a nagyvárosi jelző csak a félmillió vagy annál népesebb településeket illeti meg." (Hegedüs 1973, 8)

A nagyvárosok fogalmához kötödő népességszám-kritérium nem csak idóben, hanem térben is változik. Mivel az egyes térségek eltérỏ méretủ városokkal, településhálózati sajátosságokkal rendelkeznek, a nagyváros fogalmához kapcsolódó lélekszám, mint küszöbérték is országonként változó ${ }^{2}$, relatív fogalom, igazodván az adott ország településhálózati képéhez. ${ }^{3}$ A kelet-közép-európai szakirodalom osztályozásai a 100500 ezer fös városokat tekintik nagyvárosoknak (gyakran lehet találkozni Magyarországra vonatkozóan a „Budapest és a nagyvárosaink” kifejezéssel), a félmillió és egymillió fós városokat regionális ${ }^{4}$ központoknak, a tízmillió fós lakosságot el nem érỏ milliós városokat világvárosoknak (metropolisz), míg a legnagyobb, több mint 10 milliós településeket óriásvárosoknak (Beluszky-Kovács-Olessák 2001, 67).

Európai léptékben azonban a félmillió lakos alatti magyar "nagyvárosok” legfeljebb középvárosnak számítanak. C. A. Doxiadis egy olyan 12 szintú (ekisztikai) településrendszert vázolt fel, amelynek kezdỏ szintje, elemi egysége maga az ember. Doxiadis besorolásában a kisváros („small polis”) lélekszáma legalább 10 ezer fö, e feletti szint a város (,polis”), mely alatt a 70 és 500 ezer fö közötti településeket érti, és a településrendszer 9. szintjén lévő nagyvárosok (,small metropolis”) kategóriájába legalább félmilliós városok tartoznak (idézi Nemes Nagy 1998, 112).

Doxiadishoz igazodva jelen vizsgálatban is félmillió fó a nagyvárosok kijelölésénél figyelembe vett kritikus népességszám. A nagyvárosok népességszámára kétféle statisztika létezik: elővárosokkal együtt vagy azok nélkül. Mivel az elővárosi övezet kijelölésére az egyes európai országokban szintén eltérő a gyakorlat, jelen esetben az elővárosok nélküli népességszámot vettük figyelembe. Az Európai Unióban jelenleg 52 város népességszáma haladja meg a félmillió fö́t (World Gazetter 2007-re vonatkozó adatai).

$\mathrm{Az}$ utóbbi évek, évtizedek tendenciája, hogy több, korábban még félmillió fönél népesebb nagyváros fogyó lélekszáma e küszöbérték alá süllyedt. E városokat mégis indokoltnak tartjuk bevonni a vizsgálatba, mert esetükben nem egyszerủen egy népességfogyásról van szó, hanem a szúk adminisztratív határain túlterjedő, funkcionálisan kompakt városon belüli népességátrendeződésről. A népességfogyás ugyanis esetükben általában a szuburbanizáció folyamatával függ össze, amikor a városnövekedés súlypontja áttevődik a város közigazgatási határán kívül eső, de ahhoz fizikailag is szorosan kapcsolódó elővárosi övezetbe. Az elvándorló népesség 
jelentős része tehát nem távolodik el a várostól, hanem annak agglomerációs övezetében marad. Bár a közigazgatási értelemben vett város népességszáma fogyni kezd, a nagyvárosi agglomeráció népességszáma valójában nem csökken. Az urbanizációs folyamatokat ilyenkor egyébként gyakran követi - igaz idöben késleltetve - a közigazgatás is a nagyvárosok területének kibóvítésével.

Ez utóbbi szempontot figyelembe véve az elemzésben tehát valamennyi olyan várost nagyvárosnak tekintünk, amelynek lélekszáma valaha meghaladta a félmillió föt ${ }^{5}$. Ezzel a kibővítéssel 59-re módosult a vizsgált nagyvárosok köre. A vizsgálatba bevont nagyvárosokat az 1. táblázat mutatja be.

\section{TÁBLÁZAT}

Az Európai Unió 59 nagyvárosa és a vizsgálatban hozzájuk rendelt régióik (59 Cities of European Union and Their Regions Assigned to Them in Study)

\begin{tabular}{|c|c|c|c|c|}
\hline \multicolumn{3}{|c|}{$\begin{array}{c}\text { A nagyváros népessége és } \\
\text { népességaránya régiójän belül }\end{array}$} & \multicolumn{2}{|c|}{$\begin{array}{c}\text { Nagyvárosi régió (zárójelben, ha magasabb } \\
\text { NUTS-szinten is megjelenik önálló egység- } \\
\text { ként) }\end{array}$} \\
\hline Név & $f_{0}^{\prime \prime}, 2007$ & $\%$ & NUTS-kód & Név \\
\hline Amszterdam & 741636 & 64 & NL326 & Groot-Amsterdam \\
\hline Athén & 729137 & 19 & GR300 & Attiki (NUTS1, NUTS2 szinten is) \\
\hline Barcelona & 1581595 & 30 & ES511 & Barcelona \\
\hline Bécs & 1569316 & 100 & AT130 & Wien (NUTS2 szinten is) \\
\hline Berlin & 3383782 & 100 & DE300 & Berlin (NUTS1, NUTS2 szinten is) \\
\hline Birmingham & 984333 & 100 & UKG31 & Birmingham \\
\hline Bréma & 546501 & 100 & DE501 & Bremen, Kreisfreie \\
\hline Brüsszel & 1019022 & 100 & $\mathrm{BE} 100$ & $\begin{array}{l}\text { Arr. de Bruxelles-Capitale (NUTS1, } \\
\text { NUTS2 szinten is) }\end{array}$ \\
\hline Budapest & 1708087 & 100 & HU101 & Budapest \\
\hline Bukarest & 1877155 & 100 & RO321 & Bucuresti \\
\hline Dortmund & 588462 & 100 & DEA52 & Dortmund, Kreisfreie Stadt \\
\hline Drezda & 486854 & 100 & DED21 & Dresden, Kreisfreie Stadt \\
\hline Dublin & 1024027 & 89 & IE021 & Dublin \\
\hline Duisburg & 504358 & 100 & DEA12 & Duisburg, Kreisfreie Stadt \\
\hline Düsseldorf & 573057 & 100 & DEA1 1 & Düsseldorf, Kreisfreie Stadt \\
\hline Essen & 593085 & 100 & DEA13 & Essen, Kreisfreie Stadt \\
\hline Frankfurt & 643128 & 100 & DE712 & Frankfurt am Main, Kreisfreie Stadt \\
\hline Genova & 601951 & 70 & ITC33 & Genova \\
\hline Glasgow & 610268 & 100 & UKM34 & Glasgow City \\
\hline Göteborg & 515252 & 34 & SE0A2 & Västra Götalands län \\
\hline Hága & 474292 & 59 & NL332 & Agglomeratie 's-Gravenhage \\
\hline Hamburg & 1739117 & 100 & DE600 & Hamburg (NUTS1, NUTS2 szinten is) \\
\hline Hannover & 515140 & 46 & DE929 & Region Hannover \\
\hline Helsinki & 558457 & 41 & FI181 & Uusimaa \\
\hline Koppenhága & 1089957 & 180 & DK001 & $\begin{array}{l}\text { København og Frederiksberg } \\
\text { kommuner }\end{array}$ \\
\hline $\begin{array}{l}\text { Köln } \\
\text { Krakkó }\end{array}$ & $\begin{array}{l}963395 \\
755050\end{array}$ & $\begin{array}{l}100 \\
100\end{array}$ & $\begin{array}{l}\text { DEA23 } \\
\text { PL213 }\end{array}$ & $\begin{array}{l}\text { Köln, Kreisfreie Stadt } \\
\text { Miasto Kraków }\end{array}$ \\
\hline
\end{tabular}


Dualitások az Európai Unió nagyvároshálózatának fejlettségében az ezredfordulón.

Tér és Társadalom 21. évf. 155-178. $p$.

\begin{tabular}{|c|c|c|c|c|}
\hline \multicolumn{3}{|c|}{$\begin{array}{c}\text { A nagyváros népessége és } \\
\text { népességaránya régióján belül }\end{array}$} & \multicolumn{2}{|c|}{$\begin{array}{c}\text { Nagyvárosi régió (zárójelben, ha magasabb } \\
\text { NUTS-szinten is megjelenik önálló egység- } \\
\text { ként) }\end{array}$} \\
\hline Név & fö, 2007 & $\%$ & NUTS-kód & Név \\
\hline Leeds & 455123 & 63 & UKE42 & Leeds \\
\hline Lipcse & 500093 & 100 & DED31 & Leipzig, Kreisfreie Stadt \\
\hline Lisszabon & 517802 & 20 & PT171 & Grande Lisboa \\
\hline Liverpool & 468945 & 100 & UKD52 & Liverpool \\
\hline Lódz & 768755 & 100 & PL113 & Miasto Łódź \\
\hline London & 7421209 & 100 & UKI00 & Greater London (csak NUTS1 szinten) \\
\hline Lyon & 472317 & 29 & FR716 & Rhône \\
\hline Madrid & 3117977 & 53 & $\mathrm{ES} 300$ & Madrid (NUTS1, NUTS2 szinten is) \\
\hline Málaga & 550058 & 39 & ES617 & Málaga \\
\hline Manchester & 395515 & 29 & UKD31 & Greater Manchester South \\
\hline Marseille & 794811 & 42 & FR824 & Bouches-du-Rhône \\
\hline Milánó & 1306661 & 34 & ITC45 & Milano \\
\hline München & 1260391 & 100 & DE212 & München, Kreisfreie Stadt \\
\hline Nápoly & 988972 & 32 & ITF33 & Napoli \\
\hline Palermo & 672175 & 53 & ITG12 & Palermo \\
\hline Párizs & 6281470 & 100 & FR1? & $\begin{array}{l}\text { „Paris et petite couronne” (több } \\
\text { NUTS3-as egysége) }\end{array}$ \\
\hline Poznan & 570352 & 100 & PL415 & Miasto Poznań \\
\hline Prága & 1167050 & 100 & $\mathrm{CZ010}$ & Hlavni mesto Praha (NUTS2 szinten is) \\
\hline Riga & 742572 & 100 & LV006 & Rīga \\
\hline Róma & 2563241 & 65 & ITE43 & Roma \\
\hline Rotterdam & 598199 & 42 & NL335 & Groot-Rijnmond \\
\hline Sevilla & 701894 & 39 & ES618 & Sevilla \\
\hline Sheffield & 447047 & 86 & UKE32 & Sheffield \\
\hline Stockholm & 1253309 & 67 & SE010 & Stockholms län (NUTS2 szinten is) \\
\hline Stuttgart & 589793 & 100 & DE111 & Stuttgart, Stadtkreis \\
\hline Szófia & 1152556 & 94 & BG411 & Sofia (stolitsa) \\
\hline Torino & 872881 & 39 & ITC1 1 & Torino \\
\hline Valencia & 793332 & 33 & ES523 & València \\
\hline Varsó & 1651676 & 100 & PL127 & Miasto Warszawa \\
\hline Vilnius & 542366 & 64 & LT00A & Vilniaus (Apskritis) \\
\hline Wroclaw & 634893 & 100 & PL514 & Miasto Wrocław \\
\hline Zaragoza & 649404 & 71 & ES243 & Zaragoza \\
\hline
\end{tabular}

Forrás: World Gazetteer (2007) adatai alapján saját szerkesztés. 


\section{Felhasznált adatbázis}

A vizsgálat nemzetközi jellegéből következik, hogy a legegyszerübb alapfogalmak is gyakran teljesen más jelentést kapnak az egyes tagállamokban. Ez pedig meglehetỏsen nehezíti az elemzendő adatok összeállitását. Az integrációs folyamatoknak, azon belül is a nemzetközi statisztikai adatgyüjtés harmonizációjának köszönhetően azonban ezek a nehézségek egyre könnyebben áthidalhatók az Európai Unió vagy egyéb nemzetközi szervezetek (pl. az ENSZ) adatbázisai segítségével. Ráadásul az EU bövülésével a Közösség statisztikai hivatalának (EuroStat) adatai között már szerepelnek a bővítési folyamatban részt vevő kelet-közép-európai országok is. Jelen elemzések is az EuroStat weboldaláról nyilvánosan hozzáférhető adatokon alapulnak.

Bár a gazdasági fejlettség sokféle mutatóval mérhető, jelen esetben a nagyvárosok közötti egyenlötlenségeket a piaci, folyóáron mért egy före jutó GDP segitségével vizsgáltuk meg. Munkánk szempontjából előnyt jelent, hogy az utóbbi években az Európai Unióban felértékelödött a városok kérdése, mellyel párhuzamosan a harmonizált közösségi adatbázisokból ma már egyre több, a nemzetközi összehasonlításokat megkönnyítő nagyvárosi statisztika jelenik meg. Bár az utóbbi időben az EuroStat egyre bỏvülö adatbázist bocsát rendelkezésre a városokra vonatkozóan is, a GDP települési szinten általában nem érhetö el, csak magasabb, regionális szinten. Ezért a továbbiakban valójában nem nagyvárosokra, hanem az azokat magukban foglaló régiókra vonatkozó adatokra támaszkodik a tanulmány.

A különböző regionális szintek közül a NUTS3-as szint tủnt az elemzések számára a legalkalmasabbnak, ugyanis ez az a legalacsonyabb területi szint, amelyre még viszonylag sok információ érhetỏ el. Az ennél magasabb területi szinteken már „eltünnek” a nagyvárosok, amelyek nem külön egységként jelennek meg a területi felosztásokban, hanem nagyobb régiók részeként. NUTS3-as területi szinten viszont a nagyváros többnyire megegyezik az azt magában foglaló régióval.

Bizonyos esetekben (különösen a spanyol, a francia és az olasz nagyvárosok esetében) a nagyvárosnál nagyobb területet fed le a hozzá rendelt nagyvárosi régió. Azonban a régió adatainak elemzése esetükben is alkalmas a benne lévỏ nagyváros helyzetének bemutatására, ugyanis a NUTS3-as nagyvárosi régióra vonatkozó értékeket jelentős mértékben meghatározza a központi nagyváros. Az 1. táblázatban nyomon követhetö, hogy az egyes nagyvárosoknál mely régió értéke szerepel az elemzésekben, illetve, hogy mekkora a nagyvárosok adott régión belüli népességaránya.

Olyan esetre is láthatunk példát, amikor a nagyváros nem sorolható be egyetlen NUTS3-as egységbe sem. Ilyenkor több NUTS3-as régió aggregálásával egy nagyobb területi egység adatait érdemes figyelembe venni. Erre csupán a két európai megapolisznál (London és Párizs) volt szükség. London esetében a Greater London nevü NUTS1-es egységet, Párizsnál pedig az ún. „Paris et petite couronne” térségét vettük figyelembe. Ez utóbbi terület Paris nevü NUTS3-as egység mellett magában foglalja a vele szomszédos három NUTS3-as régiót is (Hauts-de-Seine, Seine-SaintDenis és Val-de-Marne). Mindkét megapolisz esetében a számításba vett terület nagyjából lefedi a brit, illetve francia fóváros kompakt területét. 
Az EuroStat honlapjáról elérhető NUTS3-as adatbázisban a GDP-adatok 1995 és 2004 között állnak rendelkezésre, ami egyben megszabta a vizsgálódás időbeli keretét ${ }^{6}$. Ez az időszak egyébként azért izgalmas, mert mind a kezdő, mind pedig a záró évszám egybeesik egy-egy bővítéssel. 1995-ben az ún. „északi bővítés” során az Európai Unió térsége majdnem egybeesett a fejlett Európáéval, a gazdag országok közül gyakorlatilag minden jelentősebb csatlakozni szándékozó állam az integráció részévé vált. A 2004-es ún. „keleti bővítés” során pedig első ízben ${ }^{7}$ csatlakozhattak az egykori Keleti Blokk jóval alacsonyabb társadalmi-gazdasági fejlettségi szintủ államai az egykor velük ellentétes politikai oldalhoz tartozó integrációhoz, amit gyakran aposztrofálnak Európa újraegyesítéseként. A 2004-ig tartó korszakot felölelő vizsgálatok ily módon arra nem adhatnak választ, hogy az integráció 2004-es adminisztratív kibővítése milyen hatást gyakorol az európai nagyvároshálózatra. Az integrálódás azonban nem egyik pillanatról a másikra következett be, hanem már az ezredforduló előtt elkezdődött folyamatról van szó. A vizsgált időszakot áthatja az európai integráció fokozatos elmélyülése (pl. Amszterdami Szerződés, Nizzai Reformok, euró bevezetése), illetve a keleti bővítés előkészítése (előcsatlakozási alapok, harmonizáció), mely folyamatok már 2004 előtt kihatottak a nagyvárosok gazdasági fejlődésére. Kérdés azonban, hogy Európa politikai megosztottságának eltủnését követően társadalmi-gazdasági téren is bekövetkezik-e az egységesülés.

Az EuroStat mellett a nagyvárosok 2007-es népességszámához, és a régiók földrajzi koordinátáihoz felhasználtuk a World Gazetteer nevủ internetes weboldalt, ahol valamennyi nagyváros esetében az elmúlt népszámlálások alapján becsült, 2007-es népességszámadatok vannak.

A vizsgált terület az Európai Unió ${ }^{8}$, amelynek fogalma a fokozatos bỏvitések következtében időben eltérő földrajzi tartalommal bír. Igaz, az EU a vizsgált évek többségében csupán a 15-ök területére terjedt ki, és csak a záróévben egészült ki 25 tagúvá, majd 2007-től 27 tagúvá, ebben a tanulmányban az egyszerüség kedvéért az Európai Unió elnevezés alatt a jelenlegi 27-ek közösségét értjük olyan időszakban is, amikor az integráció maihoz képest még szükebb országcsoportot érintett.

\section{A nagyvárosok gazdasági fejlettségi különbségei}

Általánosságban megállapítható, hogy a nagyvárosi régiók Európa fejlett területei közé tartoznak. Ezt támasztja alá, hogy 2004-ben az Európai Unió tíz legfejlettebb NUTS2-es régiója között nyolc ${ }^{9}$ nagyváros szerepelt (Brüsszel, Hamburg, London, Stockholm, Párizs, Bécs, Dublin és München). Az összesen $1267^{10} \mathrm{db}$ egységböl álló NUTS3-as szinten már ritkábban találunk nagyvárosokat a legfejlettebb területi egységek között. Ennek oka, hogy a legfejlettebb nem nagyvárosi régiók kis népességgel rendelkeznek ${ }^{11}$ (a 10 legfejlettebb NUTS3-as egység között egyik népességszáma sem éri el a 200 ezer főt), e gazdag vidéki NUTS3-as régiók fejlettsége kis népességsúlyuk folytán „eltünik” a nagyobb NUTS2-es régió átlagán belül, ugyanakkor a nagyvárosi régiók nagy népességükkel meghatározóak maradnak a nagyobb NUTS2-es szintü régiókon belül is. 
Az EuroStat adatai szerint 2004-ben az Európai Unió 59 nagyvárosának átlagos egy före jutó GDP-je több mint 30 ezer euró volt. Ezen átlagérték mögött azonban jelentős különbségek húzódnak meg a nagyvároshálózaton belül. Hét nagyváros értéke messze kimagaslik a mezönyböl, esetükben a fenti érték meghaladja az 50 ezer eurót. Ezek között többségben vannak a német nagyvárosok (Frankfurt, Düsseldorf, Stuttgart, Koppenhága, Brüsszel, Párizs és München). A legfejlettebb nagyváros ${ }^{12}$, Frankfurt (74 ezer euró) közel 2,5-szeresen, Düsseldorf pedig 2-szeresen múlja felül a nagyvárosi régiók átlagát.

A másik végletet pedig Kelet-Közép-Európa nagyvárosai jelentik (Riga, Krakkó, Wroclaw, Vilnius, Lódz, Bukarest és Szófia), melyek egy före jutó GDP-je a 10 ezer eurót sem éri el. Bukarest gazdasági fejlettsége a Közösség nagyvárosi átlagának 18, Szófia (4800 euró) pedig 16\%-án áll! Frankfurt am Main 15-ször fejlettebb, mint Szófia.

\section{1. ÁBRA}

Az Európai Unió nagyvárosainak egy före jutó GDP-je, 2004 (a nagyvárosi átlag $=100 \%$ )

\section{(Per Capita GDP in Cities of European Union, 2004, Average of Cities $=100 \%$ )}

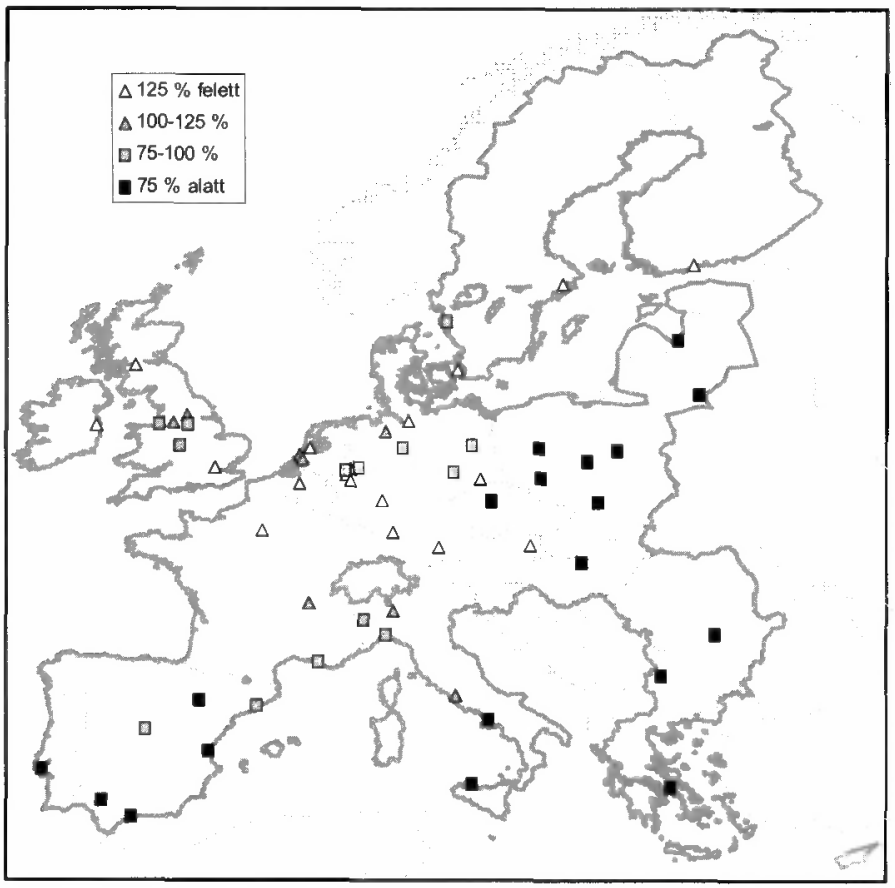

Forrás: EuroStat adatai alapján saját szerkesztés.

A fentiekból tehát kiderül, hogy az Európai Unió nagyvárosai között meglehetősen nagy gazdasági fejlettségi különbségek húzódnak. A szélső értékek fenti egyszerü felsorolása alapján is sejthető, hogy a nagyvárosok fejlettségi sorrendje erös 
regionalitást mutat (1. ábra). „Az elmúlt évtizedekben integrált, egységes nagyvárosi rendszer alakult ki Nyugat-Európában. E rendszernek a központi zónája Londontól kiindulva Párizst, a holland nagyvárosokat, Brüsszelt, Frankfurtot, Zürichet magában foglalva húzódik Milánóig. E zóna - melyet egy francia szakmunka nyomán gyakran neveznek 'kék banánnak' (Brunet 1989) - tömöríti az Európai Unió legfontosabb gazdasági parancsnoki posztjait, a transznacionális vállalatok globális vagy regionális székhelyeit, az Unió pénzügyi, politikai, kereskedelmi, technikai fejlesztési központjait. E nagyvárosi zóna a világ három döntési központjainak egyike." (Enyedi 1996, 70) A másik végletet az egykori szocialista országok és DélEurópa nagyvárosi ảtlagfejlettségi szint 75\%-át el nem érő centrumai alkotják, amelyek szintén egy tömböt alkotnak.

1995 és 2004 között az Európai Unió nagyvárosainak egy före jutó GDP-je átlagosan 1,5-szeresére növekedett. Csakúgy, mint a 2004-es gazdasági fejlettségi szint esetében, a gazdasági fejlődésük vizsgálatakor is jelentős eltéréseket tapasztalhatunk.

A leggyorsabban fejlődő nagyvárosok szinte kivétel nélkül az egykori szocialista országok közuil kerültek ki (Vilnius, Riga, Bukarest, Budapest, Prága és Varsó), Nyugat-Európát egyedül Dublin képviselte az élmezónyben. A leggyorsabban fejlödő nagyváros, Vilnius közel 4,7-szeres gazdasági fejlődést ért el, de az imént felsorolt nagyvárosok közül valamennyi esetében legalább 2,5-szer nagyobb a 2004-es érték a bázisévhez (1995) képest.

A leglassabb fejlődés ugyanakkor az egyébként a fejlettségi rangsor élmezőnyéhez tartozó német nagyvárosok esetében mutatható ki. A fejlödés üteme tekintetében leghátrányosabb helyzetú 13 nagyváros ${ }^{13}$ mindegyike német volt, egyikük esetében sem volt 1,2-szeresnél gyorsabb gazdasági növekedés.

A fentiek alapján megállapítható, hogy a statikus, illetve a dinamikus vizsgálódás ellentétes térszerkezetet mutat. Ez az ellentét nyilvánvalóan hatást gyakorol a vizsgált régiók közötti fejlettségi különbségek alakulására, méghozzá a fejlettségi különbségek csökkenése irányába. A kiegyenlítődési folyamatot igazolja a statikus (1995-ös állapot) és a dinamikus (1995-2004 közötti állapotváltozás) értékek közötti sztochasztikus vizsgálat. A 2. ábrán szépen kirajzolódik, hogy általában minél fejlettebb egy régió, annál lassabb a gazdasági fejlödése, és minél elmaradottabb, annál gyorsabb. A két adatsor között a korreláció $(\mathrm{r}=-0,7)$ fordított irányú és szoros összefüggésröl árulkodik. A három leggyorsabban fejlődó nagyváros (Vilnius, Riga és Bukarest) azonban még viszonylagos elmaradottságához képest is "túl gyorsan" fejlődik, amellyel némiképp rontja a lineáris regressziós trendvonal esetében a determinációs együttható magyarázóerejét $\left(R^{2}=0,43\right)$, ezért egy hatványkitevős trendvonal jobban illeszkedik a pontalakzatra $\left(R^{2}=0,68\right)(2$ a ábra). 


\section{2. ÁBRA}

A nagyvárosok fejlettségi szintje (1995) és a gazdasági növekedése (1995-2004)

közötti összefüggés az Európai Unióban

(Correlation between the State of Economic Development [1995] and Economic

Growth [1995-2004] of Cities in European Union)

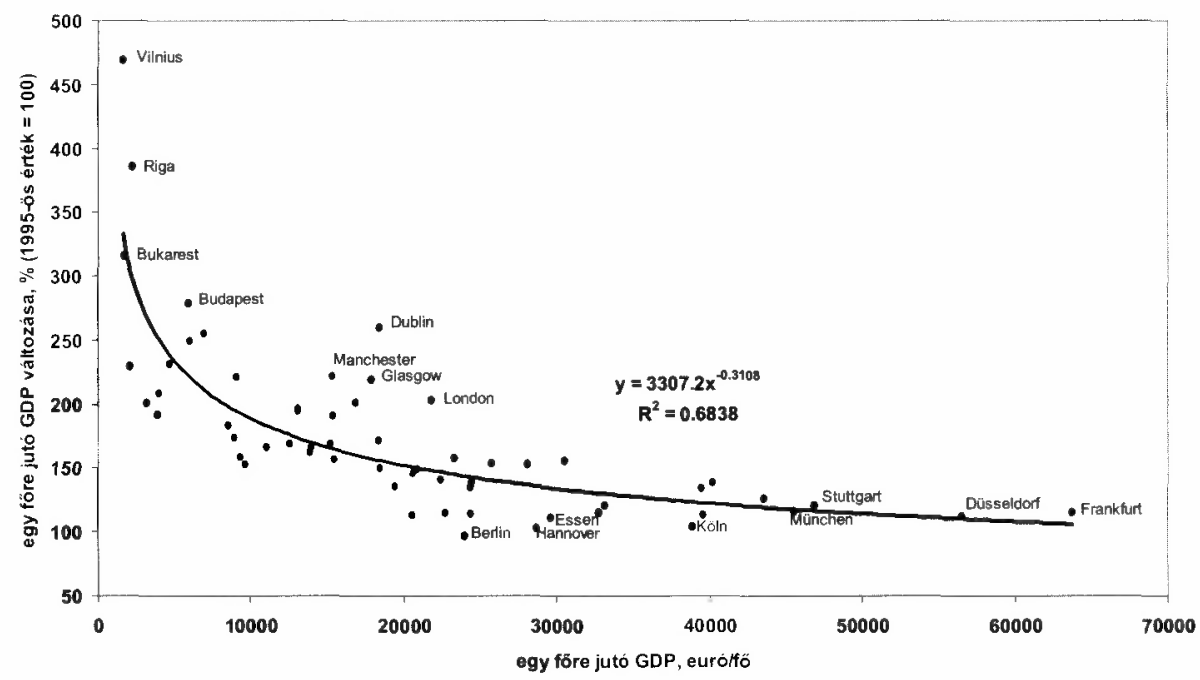

Forrás: EuroStat adatai alapján saját számítás.

A regressziós ábra által sugallt kiegyenlítődési tendenciát néhány területi egyenlötlenségi mutató (súlyozott relatív szórás, relativ terjedelem, Duál mutató, Giniegyüttható és Hoover-index) segítségével igyekeztünk alátámasztani. Az öt egyenlőtlenségi mutató 1995 és 2004 közötti bázisindexei a nagyvárosok közötti gazdasági fejlettségi különbségek csökkenését empirikusan is látványosan bizonyítják (3. ábra). Bár egyenletességében és mértékében eltérő tendenciával, de a vizsgált időszakban valamennyi mutató értékében jelentős csökkenés állapítható meg, a vizsgált időszak alatt a bázis év értékének 70-80\%-ára. Az egyenlőtlenségek legnagyobb mértékü csökkenését a relatív terjedelem esetében láthatjuk (itt a 2004-es érték a kezdóévinek csupán 73\%-a), a legkisebb csökkenést pedig a duál mutató esetében (82\%).

Az Európai Unió térszerkezetében már kimutatták (Szabó 2006), hogy a fejlettségi tagoltság bizonyos szabályszerüségeket mutat a térségek földrajzi és társadalmi tényezőivel. Kérdés, hogy ezek az összefüggések milyen erősek, ha nem a Közösség teljes területének többé-kevésbé összefüggő területalakzatát, hanem a nagyvárosok szórt, elkülönülö pontalakzatát vizsgáljuk. A nagyvárosok (különösen a fövárosok) ugyanis általában országaik legfejlettebb részei, így egyes területeken (különösen Kelet-Közép-Európában) értékeik nagymértékben eltérhetnek vidéki hinterlandjaiktól. 


\section{3. ÁBRA}

A nagyvárosok közötti gazdasági fejlettségi különbségek változásai különböző

területi egyenlötlenségi mutatók alapján, 1995-2004

(Changes of Inequalities of Economic Development among Cities by Different Inequality Indices, 1995-2004)

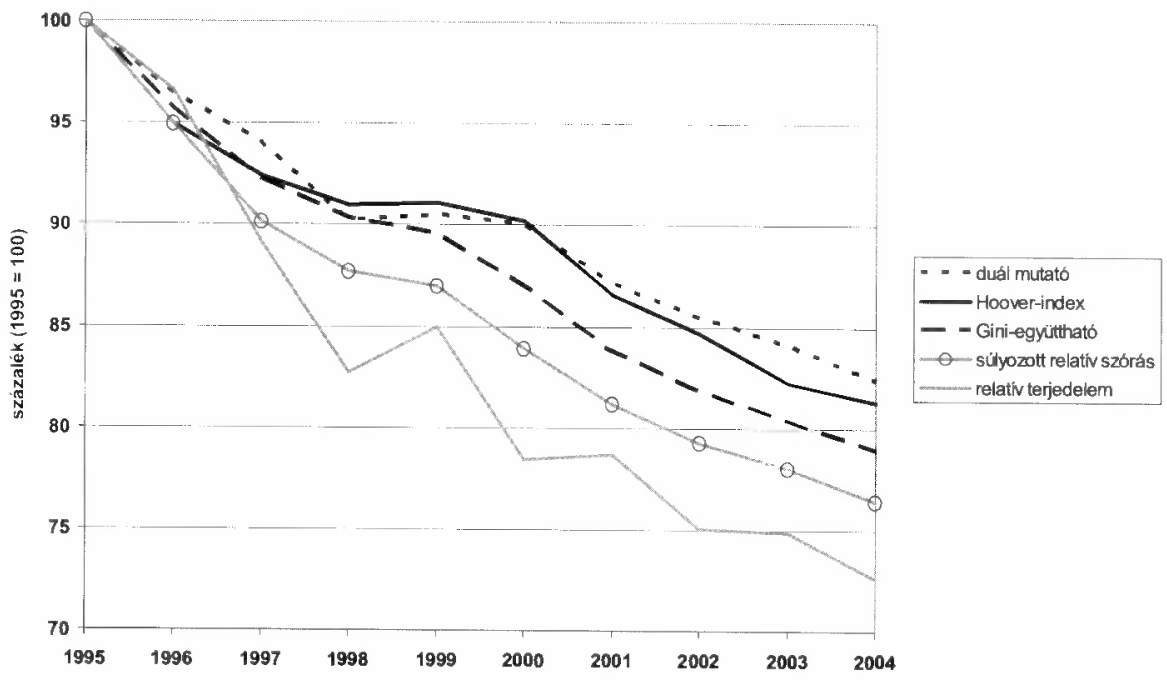

Forrás: EuroStat adatai alapján saját számítás.

A fentiekben felvázolt, nagyvárosok közötti nagymértékü kiegyenlítỏdési tendenciát még drámaibbá teszi, hogy ez egy viszonylag rövid időszak, alig egy évtized alatt ment végbe. Egy ilyen jelentős változás nyilvánvalóan nyomot hagy az egyenlötlenségekkel összefủggésben álló hatótényezők szerepében, egyes tényezők szerepe felerősödhet, másoké pedig jelentéktelenebbé válhat.

A következőkben öt különböző, az egyenlötlenségek szabályszerüségeinek hátterében húzódó tényező magyarázóerejének változását kísérjük végig 1995 és 2004 között. A vizsgált öt tényező az alábbi:

- nyugat-keleti fekvés,

- észak-déli fekvés,

- középponttól való távolság,

- történelmi megosztottság,

- városnagyság.

\section{Dualitások az Európai Unió nagyvároshálózatában}

A fent felsorolt öt tényező esetében természetesen nem azonos mértékủ a nagyvárosok közötti megosztottság. Ezek számszerúleg is mérhetők, ha a nagyvárosokat tényezőnként két-két csoportba soroljuk, majd a létrehozott csoportpárokat egymáshoz viszonyítjuk minden tényezó esetében. 
A nagyvárosok többféle módon feloszthatók két csoportra. A 2. táblázat foglalja össze a nagyvárosok vizsgálatában alkalmazott csoportba sorolási szempontokat az egyes tényezök esetében.

\section{TÁBLÁZAT}

A nagyvárosok csoportokba sorolásának módjai az öt vizsgált tényezö esetében (Methods of Division of Cities into Groups in Case of the Five Examined Factors)

\begin{tabular}{|c|c|}
\hline Tényezö (szélső esetek) & $\begin{array}{l}\text { Két nagyvároscsoport lehatárolásának alap- } \\
\qquad j^{14} \text { (elemszám) }\end{array}$ \\
\hline $\begin{array}{l}\text { Nyugat-kelet megosztottság } \\
\text { (Lisszabontól Bukarestig) }\end{array}$ & $\begin{array}{l}\text { Az Európai Unió geometriai középpontjához } \\
\text { képest nyugatabbi vagy keletebbi } \\
\text { (nyugat } 34, \text { kelet } 25 \text { ) }\end{array}$ \\
\hline $\begin{array}{l}\text { Észak-dél megosztottság } \\
\text { (Helsinkitől Málagáig) }\end{array}$ & $\begin{array}{l}\text { Az Európai Unió geometriai középpontjához } \\
\text { képest északabbi vagy délebbi } \\
\text { (észak } 36 \text {, dél } 23 \text { ) }\end{array}$ \\
\hline $\begin{array}{l}\text { Centrum-periféria } \\
\text { megosztottság } \\
\text { (Stuttgarttól Lisszabonig) }\end{array}$ & $\begin{array}{l}\text { Az Európai Unió geometriai középpontjához } \\
\text { képest } 550 \mathrm{~km} \text {-nél közelebbi vagy távolabbi } \\
\text { (centrum } 25 \text {, periféria } 34 \text { ) }\end{array}$ \\
\hline $\begin{array}{l}\text { Történelmi megosztottság } \\
\text { (1958-tól 2007-ig) }\end{array}$ & $\begin{array}{l}\text { A tagállam csatlakozása az EU-hoz az ezred- } \\
\text { forduló elötti }{ }^{15} \text { vagy utáni (régi } 48 \text {, új 11) }\end{array}$ \\
\hline $\begin{array}{l}\text { Népességszám szerinti meg- } \\
\text { osztottság } \\
\text { (Londontól Manchesterig) }\end{array}$ & $\begin{array}{l}\text { Népességszáma elỏvárosok nélkül egymillió } \\
\text { fó alatti vagy feletti (nagy } 19 \text {, kicsi } 40 \text { ) }\end{array}$ \\
\hline
\end{tabular}

Forrás: World Gazetteer adatai alapján saját számítás.

A nagyvárosokat és azok csoportjait a 3. táblázat foglalja össze. A magasabb gazdasági fejlettség a nyugati, az északi, a központi fekvésủ, a régebb idỏ óta EU-tag, valamint a milliós nagyvárosok csoportjait jellemzi. Ha az egyes tényezőket dummy-változókként fogjuk fel (ahol a gazdagabb nagyvárosok csoportja mindig 1, az elmaradottabbaké pedig 0 értéket kap), akkor az öt változóra készített korrelációs mátrix alapján kijelenthetjük, hogy a tényezök között szinte minden esetben gyenge az összefüggés. Ahogy várható volt, az egyetlen kivételt a nyugat-keleti fekvés és a történelmi megosztottság közötti viszonylag szorosabb összefüggés jelenti, hiszen a geometriai középponton áthaladó meridiántól mintegy $250 \mathrm{~km}$-re keletebbre húzódó egykori vasfüggöny vonala tulajdonképpen maga is felfogható nyugat és kelet választóvonalaként (ahogy azt politikai értelemben szokás is értelmezni). A két tényezö közötti szorosabb összefüggésre utal, hogy az egykori szocialista országok mindegyike az Unió keleti felén található, igaz a nagyvárosok többségét alkotó, szocialista múlttal nem rendelkező centrumok közül 14 szintén a középponttól keletebbre található (4. ábra). 


\section{4. ÁBRA}

A nagyvárosok és csoportjaik területi elhelyezkedése

(Territorial Location of Cities and Their Groups)

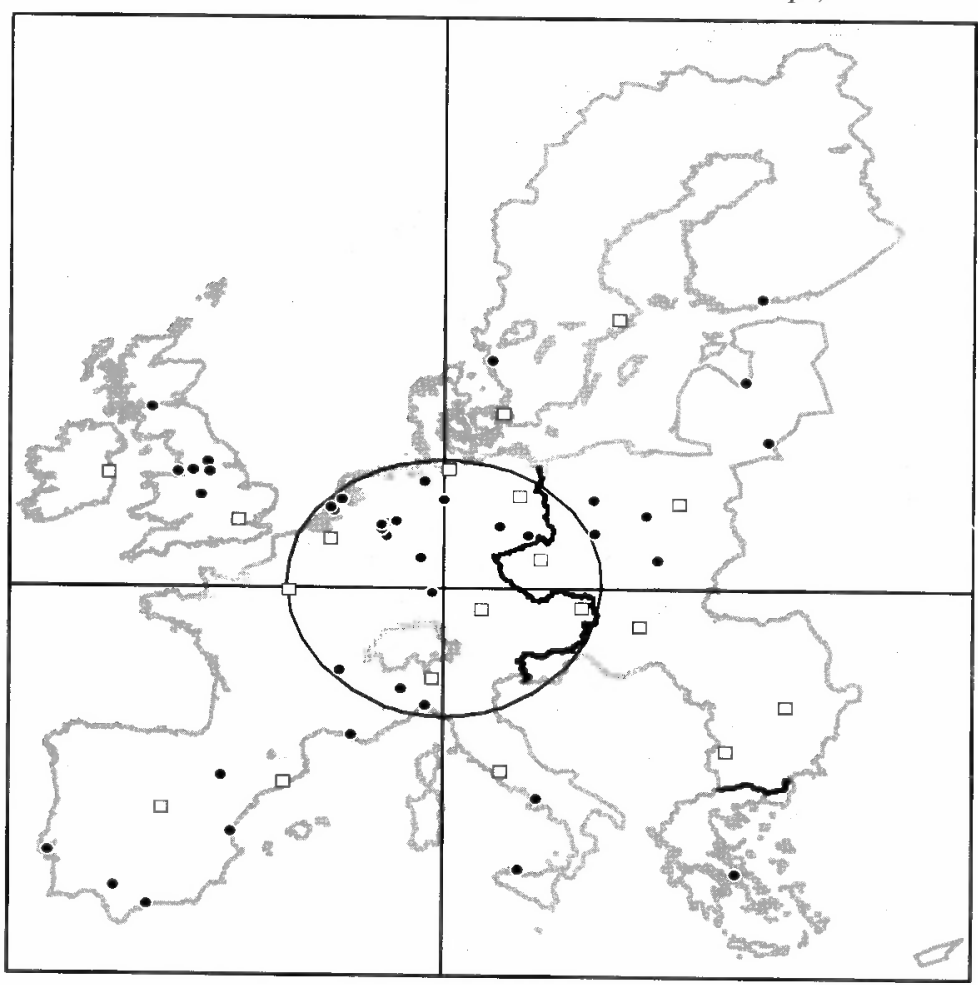

Forrás: Saját szerkesztés.

A 4. ábrán láthatjuk az egyes csoportok térbeli elhelyezkedését a hozzájuk tartozó nagyvárosokkal. A térképről leolvasható, hogy a városméret egyik térparaméterrel sem mutat szoros összefüggést, ugyanis az egymillió alatti (fekete körök) és az a feletti népességszámmal rendelkező nagyvárosok (fehér négyzetek) az Európai Unió különböző nagytájain vegyesen fordulnak elö.

A tényezök közötti viszonylag gyenge összefüggést támasztja alá az is, hogy ritka az olyan nagyváros, amely mind az öt tényező alapján a fejlett vagy a fejletlen csoportba került (3. táblázat). Csupán egy olyan nagyváros van, Brüsszel, amely mind az ${ }^{0} \mathrm{t}^{16}$ tényező alapján a fejlettebb átlagú csoportba került, olyan nagyváros viszont egyáltalán nincs ${ }^{17}$, amelyik minden esetben az elmaradottabb csoportba került volna. 


\section{TÁBLÁZAT}

A nagyvárosok értékei és csoportjai az öt vizsgált tényezỏ esetében (Values and Groups of Cities in Case of Five Examined Factors)

\begin{tabular}{|c|c|c|c|c|c|c|c|c|}
\hline Nagyváros & $\begin{array}{l}\text { Földr. } \\
\text { hossz. } \\
(\text { fok)* }\end{array}$ & $\begin{array}{c}\text { Földr. } \\
\text { szél. } \\
(f o k)^{*}\end{array}$ & $\begin{array}{c}\text { Geom. } \\
k p . \\
\text { táv. } \\
(\mathrm{km})\end{array}$ & $\begin{array}{c}\text { Csatl. } \\
\text { éve }\end{array}$ & $\begin{array}{c}\text { Nép. } \\
\left(f^{\prime \prime}\right), \\
2007^{*}\end{array}$ & $\begin{array}{c}\text { Fej- } \\
\text { lett } \\
\text { cso- } \\
\text { port }\end{array}$ & $\begin{array}{l}\text { GDPffó } \\
\text { (euró), } \\
1995^{* *}\end{array}$ & $\begin{array}{l}\text { GDPfó } \\
\text { (euró), } \\
2004^{* *}\end{array}$ \\
\hline Brüsszel & 4,33 & 50,83 & 443 & 1958 & 1019022 & 5 & 43618 & 55442 \\
\hline Frankfurt & 8,68 & 50,12 & 152 & 1958 & 643128 & 4 & 63787 & 73860 \\
\hline Düsseldorf & 6,79 & 51,24 & 332 & 1958 & 573057 & 4 & 56609 & 63553 \\
\hline $\begin{array}{l}\text { Amszter- } \\
\text { dam }\end{array}$ & 4,89 & 52,37 & 513 & 1958 & 741636 & 4 & 30552 & 47789 \\
\hline Köln & 6,97 & 50,95 & 300 & 1958 & 963395 & 4 & 38918 & 40401 \\
\hline Bréma & 8,81 & 53,08 & 464 & 1958 & 546501 & 4 & 32778 & 37707 \\
\hline Hága & 4,30 & 52,07 & 520 & 1958 & 474292 & 4 & 24482 & 34077 \\
\hline Essen & 7,00 & 51,47 & 343 & 1958 & 593085 & 4 & 29630 & 33133 \\
\hline Rotterdam & 4,48 & 51,93 & 500 & 1958 & 598199 & 4 & 22459 & 31665 \\
\hline Hannover & 9,73 & 52,40 & 383 & 1958 & 515140 & 4 & 28710 & 29571 \\
\hline Dortmund & 7,48 & 51,51 & 328 & 1958 & 588462 & 4 & 24419 & 27959 \\
\hline Duisburg & 6,75 & 51,43 & 350 & 1958 & 504358 & 4 & 22743 & 26234 \\
\hline Dublin & $-6,25$ & 53,33 & 1217 & 1973 & 1024027 & 4 & 18436 & 47907 \\
\hline London & $-0,10$ & 51,52 & 758 & 1973 & 7421209 & 4 & 21819 & 44401 \\
\hline Párizs & 2,34 & 48,86 & 544 & 1958 & 6281470 & 4 & 39575 & 53201 \\
\hline Milánó & 9,19 & 45,48 & 389 & 1958 & 1306661 & 4 & 23294 & 36891 \\
\hline Hamburg & 10,00 & 53,55 & 512 & 1958 & 1739117 & 4 & 39656 & 45091 \\
\hline Berlin & 13,38 & 52,52 & 471 & 195890 & 3383782 & 4 & 24033 & 23371 \\
\hline Glasgow & $-4,27$ & 55,87 & 1222 & 1973 & 610268 & 3 & 17908 & 39283 \\
\hline Manchester & $-2,25$ & 53,48 & 976 & 1973 & 395515 & 3 & 15336 & 34151 \\
\hline Leeds & $-1,55$ & 53,81 & 953 & 1973 & 455123 & 3 & 16896 & 34035 \\
\hline $\begin{array}{l}\text { Birming- } \\
\text { ham }\end{array}$ & $-1,91$ & 52,48 & 911 & 1973 & 984333 & 3 & 15351 & 29379 \\
\hline Sheffield & $-1,48$ & 53,39 & 926 & 1973 & 447047 & 3 & 13129 & 25864 \\
\hline Liverpool & $-2,99$ & 53,42 & 1018 & 1973 & 468945 & 3 & 13111 & 25554 \\
\hline Stuttgart & 9,19 & 48,79 & 47 & 1958 & 589793 & 3 & 46930 & 56733 \\
\hline Lyon & 4,83 & 45,76 & 515 & 1958 & 472317 & 3 & 24387 & 33080 \\
\hline Torino & 7,68 & 45,08 & 460 & 1958 & 872881 & 3 & 18445 & 27687 \\
\hline Genova & 8,93 & 44,42 & 509 & 1958 & 601951 & 3 & 15433 & 24271 \\
\hline Madrid & $-3,71$ & 40,42 & 1425 & 1986 & 3117977 & 3 & 15204 & 25819 \\
\hline Barcelona & 2,17 & 41,40 & 1030 & 1986 & 1581595 & 3 & 13967 & 23276 \\
\hline Drezda & 13,74 & 51,05 & 367 & 1990 & 486854 & 3 & 20909 & 31179 \\
\hline Lipcse & 12,40 & 51,35 & 325 & 1990 & 500093 & 3 & 20562 & 23348 \\
\hline Prága & 14,43 & 50,08 & 359 & 2004 & 1167050 & 3 & 6980 & 17849 \\
\hline $\begin{array}{l}\text { Koppen- } \\
\text { hága }\end{array}$ & 12,57 & 55,68 & 772 & 1973 & 1089957 & 3 & 40278 & 56196 \\
\hline Stockholm & 18,07 & 59,33 & 1273 & 1995 & 1253309 & 3 & 28102 & 43046 \\
\hline München & 11,58 & 48,14 & 161 & 1958 & 1260391 & 3 & 45569 & 52908 \\
\hline Bécs & 16,37 & 48,22 & 492 & 1995 & 1569316 & 3 & 33169 & 40281 \\
\hline Marseille & 5,37 & 43,31 & 714 & 1958 & 794811 & 2 & 19442 & 26484 \\
\hline Lisszabon & $-9,14$ & 38,72 & 1890 & 1986 & 517802 & 2 & 13884 & 22636 \\
\hline Zaragoza & $-0,89$ & 41,65 & 1164 & 1986 & 649404 & 2 & 12585 & 21366 \\
\hline Valencia & $-0,39$ & 39,48 & 1328 & 1986 & 793332 & 2 & 11093 & 18460 \\
\hline Malaga & $-4,42$ & 36,72 & 1782 & 1986 & 550058 & 2 & 8574 & 15726 \\
\hline Sevilla & $-5,98$ & 37,40 & 1807 & 1986 & 701894 & 2 & 8930 & 15540 \\
\hline
\end{tabular}


Dualitások az Európai Unió nagyvároshálózatának fejlettségében az ezredfordulón. Tér és Társadalom 21. évf. 155-178. p.

170 Kitekintö

TÉT XXI. évf. 2007

\begin{tabular}{|c|c|c|c|c|c|c|c|c|}
\hline Nagyváros & $\begin{array}{l}\text { Földr. } \\
\text { hossz. } \\
(f o k)^{*}\end{array}$ & $\begin{array}{c}\text { Földr. } \\
\text { szél. } \\
(\text { fok)* }\end{array}$ & $\begin{array}{c}\text { Geom. } \\
\text { kp. } \\
\text { táv. } \\
(\mathrm{km}) \\
\end{array}$ & $\begin{array}{c}\text { Csatl. } \\
\text { éve }\end{array}$ & $\begin{array}{c}\text { Nép. } \\
(f o ̈) \\
2007^{*}\end{array}$ & $\begin{array}{c}\text { Fej- } \\
\text { lett } \\
\text { cso- } \\
\text { port }\end{array}$ & $\begin{array}{l}\text { GDP/fó } \\
\text { (euró), } \\
1995 * *\end{array}$ & $\begin{array}{l}G D P / f o \\
\text { (euró), } \\
2004^{* *}\end{array}$ \\
\hline Helsinki & 24,94 & 60,17 & 1578 & 1995 & 558457 & 2 & 25743 & 39577 \\
\hline Göteborg & 12,01 & 57,72 & 987 & 1995 & 515252 & 2 & 20654 & 30359 \\
\hline Varsó & 21,02 & 52.26 & 874 & 2004 & 1651676 & 2 & 6032 & 15050 \\
\hline Róma & 12,50 & 41,89 & 814 & 1958 & 2563241 & 2 & 18360 & 31657 \\
\hline Poznan & 16,90 & 52,40 & 631 & 2004 & 570352 & 1 & 4680 & 10863 \\
\hline Riga & 24,13 & 56,97 & 1307 & 2004 & 742572 & 1 & 2288 & 8844 \\
\hline Krakkó & 19,96 & 50,06 & 745 & 2004 & 755050 & 1 & 3964 & 8283 \\
\hline Wroclaw & 17,03 & 51,11 & 571 & 2004 & 634893 & 1 & 3953 & 7588 \\
\hline Vilnius & 25,27 & 54,70 & 1239 & 2004 & 542366 & 1 & 1613 & 7568 \\
\hline Lódz & 19,46 & 51,77 & 755 & 2004 & 768755 & 1 & 3191 & 6427 \\
\hline Athén & 23,73 & 37,98 & 1657 & 1981 & 729137 & 1 & 9119 & 20216 \\
\hline Palermo & 13,36 & 38,12 & 1240 & 1958 & 672175 & 1 & 9678 & 14860 \\
\hline Nápoly & 14,27 & 40,85 & 969 & 1958 & 988972 & 1 & 9343 & 14830 \\
\hline Budapest & 19,08 & 47,51 & 708 & 2004 & 1708087 & 1 & 5978 & 16718 \\
\hline Bukarest & 26,10 & 44,44 & 1340 & 2007 & 1877155 & 1 & 1754 & 5544 \\
\hline Szófia & 23,31 & 42,69 & 1257 & 2007 & 1152556 & 1 & 2085 & 4800 \\
\hline határérték & 9,78 & 48,96 & 550 & 2000 & 1000000 & & 19899 & 30428 \\
\hline
\end{tabular}

Forrás: World Gazetteer $\left({ }^{*}\right)$ és EuroStat $\left({ }^{* *}\right)$ adatai alapján saját számítás.

Ha a csoportok átlagértékeit páronként viszonyítjuk egymáshoz, akkor megkapjuk az egyes tényezők esetén a dualitás erősségét. Ezek értékeinek évenkénti alakulása az 5. ábrán látható. Bár egyes tényezők esetében jelentős változás következett be, a tényezők egymáshoz viszonyított sorrendje a vizsgált időszakban nem változott.

\section{5. ÁBRA}

A dualitás mértékének különbségei és azok változása a vizsgált tényezöknél, 1995-2004 (Differences of Rates of Duality and Their Change at Examined Factors, 1995-2004)

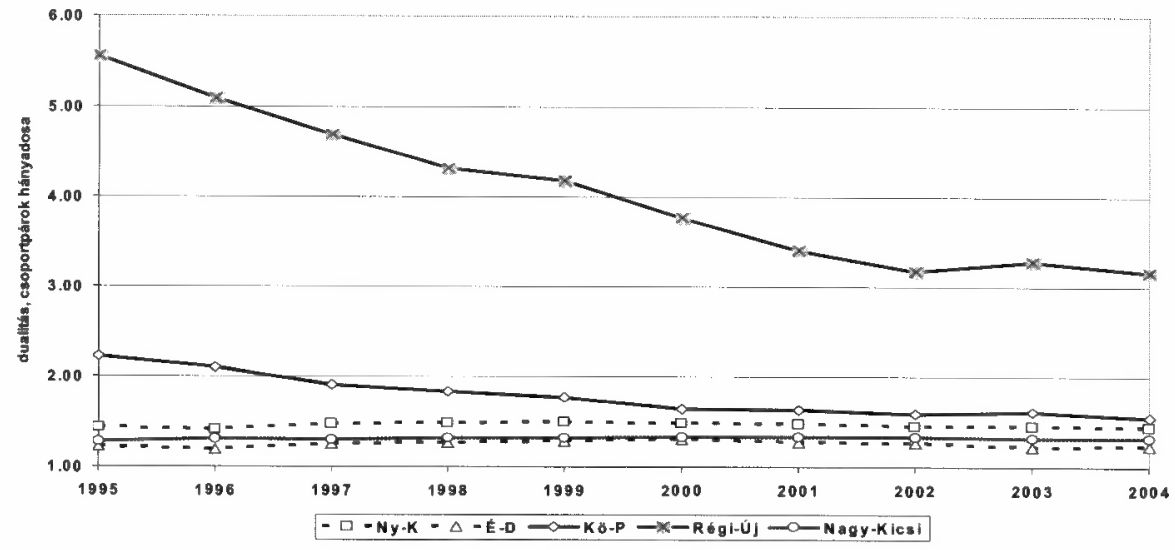

Forrás: EuroStat adatai alapján saját számítás. 
A többi tényezőhöz képest messze kitünik a történelmi megosztottság tényezője. Az egykori vasfüggöny nyoma, amely oly markánsan kirajzolódik az Európai Unió teljes területét (beleértve tehát a nem nagyvárosi régiókat is) ábrázoló fejlettségi térképeken, a nagyvároshálózaton belül is megjelenik. 1995-ben az akkori tizenöt tagállam nagyvárosai közel 6-szor voltak fejlettebbek a bỏvítési folyamatban részt vevő országokéhoz képest (5. ábra). Ez a dichotómia azóta nagyon látványosan lecsökkent, melynek eredményeként 2004-re már „csak” több mint 3-szoros a fejlettségi különbség; a vizsgált tényezök közül így is mindvégig ennél figyelhetjük meg a legmeghatározóbb dualitást.

A bázisévben szintén valamivel erősebb dualitást mutatott a többi tényezőhöz képest a centrum-periféria kettósség. Ez annyiban különbözik a történelmi megosztottság tényezőtől, hogy a többé-kevésbé ${ }^{18}$ keleti perifériának tekinthetö, volt szocialista államokhoz tartozó nagyvárosok kiegészülnek a Közösség északi, nyugati és déli perifériáival. Itt már kisebb a szegényebb és a gazdagabb csoport közötti kontraszt, amely ráadásul egyre inkább eltörpül. Ez esetben is egy erőteljes kiegyenlítődési tendencia figyelhető meg, hiszen 1995-ben a centrumtérségek nagyvárosai még átlagosan 2,2-szer fejlettebbek voltak a periférikus helyzetü társaikhoz képest, kilenc évvel később a hányados már csak 1,5-szeres eltérést jelez, amely már alig erősebb a többi tényezőhöz képest.

A maradék három tényezőre a mindvégig közel azonos mértékü, nagyon alacsony fokú dualitás jellemző, melynek erőssége alapján a tényezők csökkenő sorrendben: nyugat-keleti, városnagyság szerinti, majd észak-déli megosztottság. A változás mértéke esetükben szinte alig érzékelhetö. Az előző tényezőknél ismertetett látványos kiegyenlítődési tendenciákkal szemben a városnagyság tényezőjénél a két csoport közötti különbség lassú emelkedése mutatható ki. A milliós metropoliszok elönye 1,27-röl 1,32-szeresre nött.

Ahogy arra már több, az Európai Unió teljes területére elvégzett kutatás is rámutatott (Szabó 2006), a földrajzi irányok közül a nyugat-keleti bizonyult meghatározóbbnak. Mindkét térparaméter esetében megfigyelhetö, hogy nagyjából a vizsgált időszak közepéig (1999-ig) kis mértékben növekedett a nagyvárosok fejlettsége közötti kontraszt, majd a periódus második felében megfordult a korábbi tendencia, a két nagyvároscsoport átlaga között mérséklödött a fejlettségi különbség. A jelenség oka az északnyugaton fekvő brit és ír nagyvárosoknak inkább a periódus elejére jellemző dinamikus növekedése.

Ha a nyugat-keleti dimenzió értékeit összevetjük - a szintén nyugat-keleti kettösséget képviselö, csak kissé keletebbi választóvonallal megjelenö - történelmi megosztottsággal, akkor szembeötlő a különbség. Ennek oka, hogy a földrajzi középponthoz kötött keleti csoportba az egykori Keleti Blokk mellé bekerültek azok a jóval fejlettebb német nagyvárosok is, amelyek vontatott fejlődésükkel „fékezik" a keleti csoport átlagos gazdasági fejlődését. Ugyanakkor ily módon a szóban forgó városok nem lassítják a kontinens nyugati perifériáinak úgyszintén gyors felzárkózását, melynek eredményeként a vizsgált időszak első felében létrejöhetett az a furcsa helyzet, hogy miközben a történelmi megosztottság tekintetében egy határo- 
zott kiegyenlítödés látszott, a nyugati nagyvárosok enyhe mértékben ugyan, de tovább erősítették fejlettségi elönyüket keleti társaikkal szemben.

\section{A vizsgált tényezők szerepe a nagyvárosok közötti egyenlőtlenségekben}

A különbözö tényezők alapján lehatárolt csoportok közötti egyenlötlenség többféle területi egyenlőtlenségi mutatóval is mérhető, ezek egyike a Hoover-index, amely „azt adja meg, hogy az egyik vizsgálati ismérv, társadalmi-gazdasági jelenség mennyiségének hány százalékát kell a területegységek között átcsoportosítanunk ahhoz, hogy területi megoszlása a másik jellemzöével azonos legyen." (Nemes Nagy 2005, 112) Jelen esetben a népesség nagyvárosok közötti eloszlásával vetettük össze a GDP eloszlását, a vizsgált egységnek pedig 59 nagyvárost, illetve az ezek összevonásából tényezőnként létrehozott 2 csoportot vettük.

\section{6. ÁBRA}

A tényezök szerepének változásai a nagyvárosok közötti egyenlötlenségekben a Hoover-index alapján, 1995-2004

(Changes of Role of Factors in Inequalities among Cities by Hoover-index, 1995-2004)
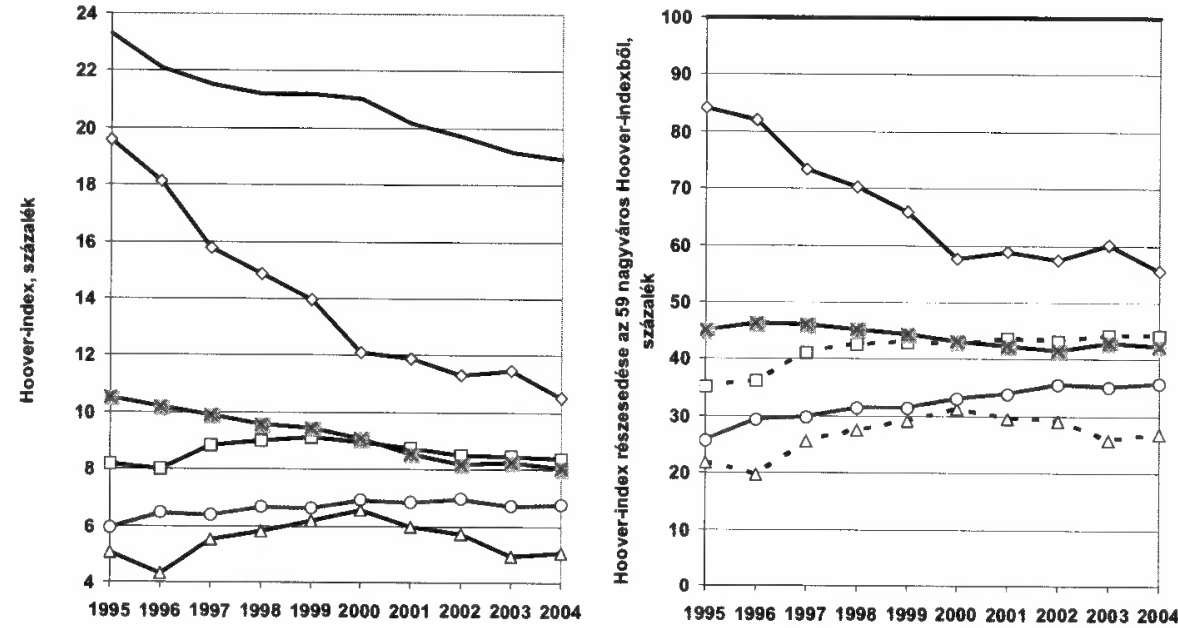

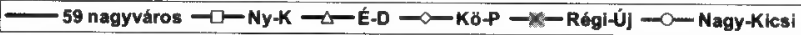

Forrás: EuroStat adatai alapján saját számítás.

A Hoover-index a különbségek megállapításán túl lehetőséget nyújt arra is, hogy megvizsgáljuk az egyes tényezők esetében megjelenő kettősség szerepét a nagyvároshálózaton belüli általános területi egyenlőtlenségekböl. A tényezőnként kiszámított Hoover-index értékei ugyanis kifejezhetők az 59 nagyváros között számított Hoover-index értékének százalékában. Ez a százalékos érték azt jelzi, hogy a nagyvárosok közötti jövedelem-átcsoportosítások mekkora hányada történik a két 
csoport között (azaz mennyire képez markáns választóvonalat a csoporthatár a fejlett és elmaradott nagyvárosok között), illetve mekkora hányada a csoportokon belül (azaz mennyire homogének a csoportok).

A 6. ábra bal oldalán az eredeti Hoover-index értékek láthatók, a jobb oldalon pedig ezeknek az 59 nagyvárososra kiszámított Hoover-index százalékában kifejezett formája (6. ábra). Az ábra bal felén a duál mutatóhoz hasonló helyzet látszik, azaz a történelmi megosztottság és a centrum-periféria korábban meghatározó jelentőségének halványodása, a két földrajzi irány szerinti egyenlőtlenségek hullámzása, a városnagyság szerinti kettősség enyhe emelkedése mutatható ki, egyébként e három utóbbi, gyengébb tagoltságot jelző dimenzió egymáshoz viszonyított sorrendje is hasonló az elözőekben ismertetetthez.

Jelentős különbség azonban, hogy ezúttal nem a történelmi megosztottság, hanem a centrum-periféria kettősség esetében jelenik meg a legmarkánsabb egyenlötlenség. Ennek matematikai, módszertani magyarázatát az adja, hogy a két csoport között számított Hoover-index értékét a gazdasági fejlettségen túl befolyásolhatja a csoportok népesség-, illetve GDP-aránya az Unión belül. Az új tagállamokhoz tartozó nagyvárosok csupán $12 \%$-át adják a Közösség népességének, ugyanez az arány a szintén elmaradottabb csoporthoz tartozó periferikus helyzetú nagyvárosok esetében $64 \%$. Mindkét esetben - lévén szegényebbek -, a csoportok Unión belüli gazdasági súlya elmarad a népességarányuktól. Az Unión belüli GDP-részesedés azonban az első esetben semmiképp nem térhet el 12\%-nál nagyobb mértékben a népességaránytól. Így a történelmi megosztottság rendkívül „aránytalan” csoportjai között eleve korlátozottabb az esély a magasabb Hoover-index értékekre.

A 6. ábra jobb oldalán már nem az egyes tényezők esetében tapasztalt egyenlötlenségek nagyságát láthatjuk, hanem ezek szerepét a nagyvárosok közötti általános fejlettségi különbségekben. A centrum-periféria megosztottság nem csupán abszolút mértékben mérséklödött, hanem a szerepe is a nagyvároshálózaton belüli általános fejlettségi különbségekben. Az időszak elején a nagyvárosok fejlettségi rangsorában igen erősen érvényesült a központ-periféria megosztottság, amely az összes nagyváros közötti egyenlötlenség 84\%-át tette ki. A geometriai középponttól számított $550 \mathrm{~km}$ sugarú körön belül Torino, Genova és Prága kivételével valamennyi nagyváros átlag feletti fejlettségü volt, a perifériákon pedig az észak-európai nagyvárosokat (Koppenhága, Göteborg, Stockholm és Helsinki), valamint Londont leszámítva mindegyik átlag alatti fejlettségü volt. Az eltelt időszak alatt bekövetkezett radikális változások a centrum-periféria reláció jelentőségének mérséklődéséhez vezettek, amelyben nem csupán a volt szocialista országok, hanem a nyugati perifériák nagyvárosainak gyors ütemü felzárkózása is szerepet játszott. 2004-re már egyre több átlag alatti fejlettségủ nagyváros jelent meg a centrumban is (a korábban felsoroltak mellett lassabban fejlődő német nagyvárosok: Berlin, Dortmund, Duisburg, Hannover és Lipcse), miközben egyre több centrumtól távolabbi nagyváros átlag feletti fejlettségüvé vált (a korábban felsoroltakon kívül ${ }^{19}$ Dublin, Glasgow, Leeds, Manchester és Róma). 
Az előzöekben felvázolt helycserék is igazolják, hogy a központ-periféria dichotómia súlyvesztésében nem elsősorban a volt szocialista országok sokat emlegetett felzárkózása, hanem sokkal inkább a nyugati perifériák nagyvárosainak a centrumtérséggel szembeni gyors ütemú gazdasági növekedése játszott fószerepet. Ezt szépen igazolja az egykori vasfüggöny vonala szerinti megosztottság szerepének stagnálása, enyhe hullámzása az egyenlôtlenségekben. Az 59 nagyváros esetében kimutatott kiegyenlitődésben nem annyira az új és régi tagállamok centrumai közötti, hanem inkább a régiekén belüli nivellálódás játszott kulcsszerepet.

Ezzel a jelenséggel függ össze az is, hogy a nyugat-kelet kettósség szerepe itt szinte egyenrangúvá vált a történelmi megosztottságéval (sőt 2000 óta már erősebb is). Ennek a hátterében sem elsósorban a volt szocialista nagyvárosok, hanem inkább a nyugati perifériák gyors felzárkózása, illetve a keleti területek szocialista múlttal nem rendelkező nagyvárosainak vontatottabb gazdasági fejlődése áll. Ezt bizonyítják azok a nagyvárosok, amelyek a vizsgált időszak alatt átlag felettiböl az alatti fejlettségüvé váltak, illetve fordítva. Az átlag felettiek csoportjához átkerült nagyvárosok Róma kivételével az Európai Unió nyugati feléhez (felsorolt angol nagyvárosok és Dublin), míg az átlag alattiakhoz átkerültek kivétel nélkül a keleti feléhez (felsorolt német nagyvárosok és Göteborg) tartoznak. Ezek alapján kijelenthetô, hogy az Európai Unió nagyvároshálózatán belül bár még mindig az egykori vasfüggöny mentén húzódik a legmarkánsabb fejlettségi szakadék, az átlag feletti és az alatti nagyvárosokat elválasztó vonal inkább egy nyugatabbi, a Közösség geometriai közepén áthaladó délkörnek felel meg.

A népességszám szerinti megosztottság az egyetlen olyan vizsgált tényező, amely 1995 óta, ha enyhe mértékben is, de többé-kevésbé folyamatos erősödést mutatott. Ez különösen akkor figyelemre méltó, ha figyelembe vesszük, hogy az 59 nagyváros között számított egyenlötlenségek mérséklődnek, ez alapján e dimenzió szerinti megosztottság arányaiban még inkább felértékelődik. 2004-ben már az egyenlőtlenségek 36\%-át tette ki a népességszám szerinti megosztottság.

Az Európai Unió nagyvároshálózatára már korábban megfogalmazott általános kiegyenlítődési tendenciából következik a fejlettebb térségek lassabb, az elmaradottabbaknak pedig gyorsabb gazdasági fejlődése. Ez egyaránt igaz az egymillió alatti és az afeletti lélekszámú nagyvárosokra. Azonban mind a szegényebb nagyvárosok felzárkózásában, mind pedig a fejlettebbek lefelé nivellálódásában a milliósnál kisebb nagyvárosok „húzzák a rövidebbet”. A fejlett nagyvárosok közül a nagyobb metropoliszokra kevésbé volt jellemzó a lassú gazdasági növekedés, mint az egymillió lakos alattiakra. Az elmaradottabb nagyvárosok közül szintén a nagyobbak fejlödtek gyorsabban (ide tartoznak Dél- és Kelet-Közép-Európa metropoliszai), míg a kisebbek között olyanok is akadtak, amelyek felzárkózás helyett rontottak pozíciójukon (Marseille és Torino). 


\section{Összefoglalás}

Az Európai Unió térszerkezetének fejlett elemei közé tartozó nagyvárosok között jelentős fejlettségi különbségek húzódnak. A legfejlettebb nagyvárosok NyugatKözép-Európában (elsősorban Németország területén), a legelmaradottabbak pedig az integráció keleti perifériáin találhatók. A tágabban értelmezett ezredfordulón azonban igen gyors csökkenés ment végbe a nagyvárosok közötti egyenlötlenségekben. Ezt több területi egyenlőtlenségi mutató (súlyozott relatív szórás, relatív terjedelem, duál mutató, Gini-együttható, Hoover-index) határozottan igazolja, amennyiben értékeik alig egy évtized alatt 70-80\%-ukra csökkentek.

A látványos kiegyenlítődési folyamattal párhuzamosan átalakulnak a nagyvárosok közötti egyenlötlenségekkel többé-kevésbé összefüggésben álló különböző földrajzi és társadalmi tényezök. A tanulmányban öt tényezőn keresztül vizsgáltuk meg az Európai Unió nagyvároshálózatában megjelenő dualitások erősségét, ezen megosztottságok szerepét a Hoover-indexszel mért egyenlötlenségekben.

Ezek alapján megállapítható, hogy még mindig az egykori vasfüggöny vonala a legmarkánsabb fejlettségi törésvonal a nagyvároshálózaton belül, igaz a volt szocialista országok nagyvárosainak felzárkózása nyomán ez rohamosan halványodik. A vizsgált időszak elején még viszonylag jelentősebb centrum-periféria kettősség is erősen háttérbe szorul, amelyért már nem annyira a keleti, mint inkább a nyugati perifériák gyors felzárkózása, illetve a centrumtérségek vontatott gazdasági növekedése okolható.

A Hoover-indexszel végzett számítások a duál mutató alapján a várthoz képest kissé eltérő módon mutatták a tényezök befolyásoló szerepének sorrendjét a nagyvárosok közötti egyenlötlenségek alakulásában. Ezt a Hoover-index matematikai háttere magyarázza, melynél felértékelődik a nagyvárosok átlaghoz viszonyított pozíciója, amely alapján a történelmi megosztottság már kevésbé bizonyul jó választónak, hiszen a régi tagállamok nagyvárosai közül is számos átlag alatti fejlettségü. Itt szintén nem annyira a kelet-közép-európai nagyvárosok felzárkózása játszik kulcsszerepet. A nyugati perifériákon az angol, ír nagyvárosok gyors fejlödésüknek köszönhetően átlag feletti fejlettségủvé váltak, míg a centrumtérség keleti oldalán fekvố német nagyvárosok lassabb gazdasági növekedésük miatt átlag alattiakká. Ezek a folyamatok a korábban szinte domináns centrum-periféria reláció szerepének oldódását eredményezték, valamint azt, hogy az átlag feletti és alatti nagyvárosokat elválasztó vonalnak a vasfüggöny helyett inkább az attól nyugatabbra húzódó geometriai középvonal felel meg. Az átalakulás kis mértékben erösítette a városnagyság szerepét is az egyenlőtlenségekben.

\section{Jegyzetek}

${ }^{1}$ A városok körét az Európai Unió országai eltérő módon határozzák meg. A tagállamok többségében a népesség lélekszámától függően nyilvánítják várossá az egyes településeket, de ez a határ szélsőségesen változó. Az országok jelentős részénél a kritikus népességszám a várossá nyilvánítás egyetlen kritériuma. 
Egyes ritkábban lakott, fejlett északi országoknál (Dánia, Svédország) már 200 fố elég ahhoz, hogy egy települést városnak tekintsenek. Írországban az alsó határ 1500 fö. Több tagállam esetében ez a szám 2000 fö (pl. Franciaország, Hollandia, Luxemburg és Nẻmetország), Ausztriában a kritikus méret 5000, míg a dél-európai országoknál (Görögország, Olaszország, Portugália és Spanyolország) pedig 10 ezer fỏ. Belgium esetében komplex mutatók alapján (pl. központi funkciók megléte, foglalkozási szerkezet, népsürüség, infrastruktúra fejlettsége stb.) funkcionális értelemben különítik el a várost a falutól. Hazánk és a kelet-közép-európai országok tőbbsége is ez utóbbi kategóriába tartozik. Ráadásul meg kell jegyezni, hogy a városi cím megitélésének kritériumrendszere nemcsak térben, hanem idöben is változhat (gondoljunk csak a hazai várossá nyilvánítás szabályainak kiürülésére) (United Nations 1993; Beluszky-Kovács-Olessák 200I). „A városi népességre vonatkozó statisztikai adatok tehát nem azonos tartalmat tükröznek, egyaránt magukban foglalják a 250 lakosú városkákat, illetve a sok milliós népességủ nagyvárosokat." (Bernek-Sárfalvi 1996, 46) Nemzetközi összehasonlításoknál ezért gyak-

2 ran a 10 ezer fónél népesebb településeket tekintik városoknak.

Nem is minden nyelvben jelenik meg a nagyváros fogalma. A német nyelv például használja a "Grosstadt" kifejezést, az angolban azonban leginkább a „city” szó feleltethető meg a nagyváros fogalmának, amely két értelemben használatos. Egyrészt a „city” szükebb értelemben csupán a nagyobb városok központjára, belvárosára vonatkozik, másrészt magát a város egészét jelentheti, csakúgy mint a „town” kifejezés. Ez utóbbival szemben a „city” fogalmát áltatában nagyobb méretű településekre használják. Így a magyar nagyváros angol megfelelője lehet „large city”, de önmagában a „city” fogalma is használható.

${ }^{3}$ Ehhez hasonlatos probléma a természetföldrajzban a hegységek és a dombságok közötti elkülönítés országonként eltéró módszere, amely erősen függ az adott ország domborzati viszonyaitól. A viszonylag alacsony átlagmagasságú Magyarországon az 500 méternél magasabban fekvő domborzati formákat a magyar természetföldrajzi szakirodalom hegyeknek (hegység, középhegység) nevezi. Ezzel szemben a változatosabb függőleges tagoltsághoz „,szokott” romániai geomorfológiai szakirodalomban csak a tengerszintnél 800 méterrel magasabban fekvö területeket tekintik hegységeknek.

4

Itt a regionális jelző nem feltétlenül a Magyaroroszágon NUTS2-es szintet alkotó tervezési-statisztikai régiókra, hanem inkább nagytérségekre (esetenként országhatárokon túlra is kiterjedő tájegységekre) vonatkozik.

5 A fenti módosítás összesen hét nagyvárost érint: ebből négy brit (Leeds, Liverpool, Manchester, Sheffield), egy holland (Hága), egy francia (Lyon) és egy német város (Drezda). Drezda esetében már nem annyira a szuburbanizáció folyamata, mint inkább az újraegyesítés generálta belnémet migráció játszik föszerepet kiegészülve a természetes fogyással.

${ }^{6}$ Bár az EuroStat egységesített adatbázisa csak 2004-ig közöl GDP-adatokat, elképzelhető, hogy egy-egy tagállamra már elérhető késöbbi évekre is adat. Azonban, mivel ez nem teljes körü, nem vettük figyelembe, ráadásul a közösségi statisztikai hivatal által közzétett adatbázis előnye, hogy már eleve harmonizálva, euróban kifejezve állnak rendelkezésre a GDP-adatok. Néhány esetben ugyanakkor épp az EuroStat harmonizált adatbázisa volt hiányos, Romániára például csak 1998 óta állnak rendelkezésre adatok. Ez esetben a későbbi évek tendenciái alapján megbecsültük a hiányzó évek adatait, így végül 1995 és 2004 között valamennyi évre és valamennyi NUTS3-as egységre elérhetővé váltak az adatok.

${ }^{7}$ Nem számítva az egykori NDK területét, amely a német újraegyesitéssel már 1990-ben a Közösség részévé vált.

${ }^{8}$ A vizsgálati terület nem terjed ki a Közösség Európán kivuüli területeire: francia tengerentúli területek, Kanári-, Azori-szigetek, Madeira, Ceuta és Melilla.

9 A két nem nagyvárosi régió közül az egyik a London elóvárosi övezetéhez tartozó Berkshire, Buckinghamshire and Oxfordshire (Reading és Oxford régiója) volt.

${ }^{10}$ Valójában ennél több NUTS3-as régió található az Európai Unióban, a korábban már említett London és Párizs környéki régiók összevonásával, illetve a Közösség tengerentúli megyéinek elhagyásával azonban az elemzésben kevesebb NUTS3-as egység szerepel.

${ }^{11}$ A legfejlettebb NUTS3-as egység a németországi München Landkreis ( 85 ezer euró GDP/fö) - amely a dél-német nagyváros elóvárosi övezete - például alig több mint 25 ezer fővel rendelkezik.

12 Megjegyzendő, hogy valójában a legmagasabb egy fỏre jutó értékkel rendelkezỏ NUTS3-as egység az EU-ban Inner Londor - West volt (több mint 120 ezer euró!), azonban ahogy arról már korábban szó volt, a londoni NUTS3-as egység aggregálásával a brit fỏváros Greater London néven szerepel az adatbázisban, amelyben öt NUTS3-as régió értéke átlagolódik. Ugyanez igaz Párizsra is, ez esetben 
Paris (3.), illetve Hauts-de-Seine (5.) NUTS3-as egységek „tünnek el” az európai fejlettségi rangsor élmezönyéből.

13

Ez különösen azért figyelemre méltó, mert Németországot összesen 14 nagyváros képviseli. Közöttük az egyetlen viszonylag gyorsabban fejlödő Drezda, amely egykoron szintén egy volt szocialista országhoz tartozott. Söt, a többi német nagyvåroshoz képest kissé gyorsabban fejlödö Drezda sem érte el a Közösség nagyvárosainak átlagos gazdasági fejlödési ütemét.

A térparaméterek szerinti csoportalakításoknál felhasznált geometriai középpont kiszámítása nem csupán az 59 nagyvároson, hanem a teljes vizsgált teret lefedő 1267 darab NUTS3-as egységen alapul, ahol a régiókhoz a legnépesebb településeik földrajzi koordinátáit rendeltük. Az ily módon kapott geometriai középpont koordinátái: északi szélesség 48,96 fok, keleti hosszúság 9,78 fok, a kitüntetett pont a nagyvárosok közül Stuttgarthoz van legközelebb, attól alig 47 km-re északkeletre.

${ }^{15}$ Kérdésként merïlhet fel az egykori kelet-német nagyvárosok (Berlin, Drezda és Lipcse) hovatartozása. Bár kétségtelenül ezek az egykori szocialista blokkhoz tartoztak, a vizsgálatban mégis a többi német várossal együtt a Nyugati Blokkhoz kerültek. Berlin esetében ez kevésbé problematikus, hiszen a város nyugati fele korábban is az akkori fejlett világhoz tartozott. A másik két német nagyvárost azért vettük inkább a nyugatiak közé, mert a vizsgált időszakban már jó néhány év eltelt az újraegyesítés óta, gazdasági fejlettségük felülmúlja az egykori Keleti Blokk valamennyi nagyvárosáét, ráadásul vontatott fejlődési dinamikájukban is inkább a nyugat-német nagyvárosok sorsában osztoznak. Ủgy tủnik, esetükben tehát az országhatás erőteljesebb, mint az egykori történelmi blokkhoz tartozás öröksége.

16 Több nagyváros négy tényező alapján is a fejlettebb csoportokhoz tartozik. Az északnyugatnémetországi és hollandiai nagyvárosok (Bréma, Dortmund, Duisburg, Düsseldorf, Essen, Frankfurt, Hamover, Köln, Amszterdam, Hága és Rotterdam) a kisebb népességszámuk, London és Dublin a magterülettôl való távolságuk, Párizs és Milánó a geometriai középponttól számított délebbi, Berlin és Hamburg pedig keletebbi fekvése miatt nem szerepel minden kategóriában a legfejlettebb csoportban.

${ }^{17}$ Több nagyváros viszont csupán egy tényező alapján került valamely fejlettebb csoportba. Budapest, Bukarest és Szófia csak a nagyobb lélekszámuk miatt, Athén, Nápoly és Palermo a régebbi EU tagságuknak köszönhetően nem lettek minden tényező szerint az elmaradottabb csoportok tagjai. A lengyel és balti nagyvárosokat (Krakkó, Lódz, Poznan, Wroclaw, Riga és Vilnius) pedig csupán az északi fekvésủk ,mentette meg” attól, hogy egyik esetben se legyenek a fejlett csoportban.

${ }_{18}^{18}$ Prága az egyetlen olyan volt szocialista nagyváros, amely a központi területhez tartozik.

${ }^{19}$ A felvázolt trendnek ellentmond, hogy a periferikus helyzetü, korábban még nagyvárosi átlag feletti Göteborg időközben átlag alatti fejlettségủvé vált.

\section{Irodalom}

Barta Gy.-Beluszky P. (szerk.) (1999) Társadalmi-gazdasági átalakulás a budapesti agglomerációban. A budapesti agglomeráció kölcsönkapcsolatai 1. Regionális Kutatási Alapitvány, Budapest.

Beluszky P.-Kovács Z.-Olessák D. (szerk.) (2001) A terület-és településfejlesztés kézikönyve. Magyarország kézikönyvtára sorozat. CEBA Kiadó, Váckisújfalu.

Bernek Á. (2000) A globális vilảg „új gazdaságföldrajza”.--Tér és Társadalom. 4. 87-107. o.

Bernek Á-Sárfalvi B. (1996) Altalános társadalomfóldrajz a középiskolák számára. Nemzeti Tankönyvkiadó, Budapest.

Cséfalvay Z. (1999) Budapest mint Kelet-Közép-Európa centruma? - Csontos J.-Lukovich T. (szerk.) Urbanisztika 2000. Akadémiai Kiadó, Budapest. 127-144. o.

Enyedi Gy. (1996) Regionális folyamatok Magyarországon az átmenet idöszakában. Hilscher Rezsö Szociálpolitikai Egyesület, Budapest.

Enyedi Gy. (1997) A sikeres város. - Tér és Társadalom. 4. 1-7. o.

Enyedi Gy (1998) Budapest - kapuváros? - Glatz F. (szerk.) Budapest - nemzetközi város. Magyar Tudományos Akadémia, Budapest. 47-55. o.

Enyedi Gy. (1999)A magyar településfejlódés integrációs kihivásai az ezredfordulón. - Csontos J.Lukovich T. (szerk.) Urbanisztika 2000. Akadémiai Kiadó, Budapest. 117-125. o.

Faragó L. (2006) A városokra alapozott területpolitika koncepcionális megalapozása. - Tér és Társadalom. 2. 83-102. o.

Hegedús M. (1973) Gazdasági fejlódés és az urbanizáció. Akadémiai Kiadó, Budapest.

Kovács Z. (2002) Az urbanizáció jellemzői Kelet-Közép-Európában a posztszocialista átmenet idején. Földrajzi Közlemények. 1-4. 57-78. o. 
Lengyel L. (1999) „Budapestország” mítoszai. - Csontos J.-Lukovich T. (szerk.) Urbanisztika 2000. Akadémiai Kiadó, Budapest. 111-116, o.

Nemes Nagy J. (1998) A tér a társadalomkutatásban. Bevezetés a regionális tudományba. Hilscher Rezső Szociálpolitikai Egyesület, Budapest.

Nemes Nagy J. (szerk.) (2005) Regionális elemzési módszerek. Regionális Tudományi Tanulmányok 11. ELTE Regionális Földrajzi Tanszék, MTA-ELTE Regionális Tudományi Kutatócsoport, Budapest

Szabó P. (2006) A fejlettség makroregionális különbségeinek alakulása az Európai Unióban. III. Magyar Földrajzi Konferencia, Budapest. CD-ROM. MTA Földrajztudományi Kutatóintézet, Budapest.

United Nations (1993) World Urbanization Prospects. The 1992 Revision. Department of Economic and Social Information and Policy Analysis. United Nations, New York.

http://www.world-gazetteer.com/

http://epp.eurostat.ec.europa.eu/ 